\title{
Computational Thinking and Tinkering: Exploration Study of Primary School Students' in Robotic and Graphical Programming
}

\author{
${ }^{1}$ Anna Felicia, ${ }^{2}$ Sabariah Sha' rif, ${ }^{3}$ WK Wong \& ${ }^{4}$ Muralindran Mariappan \\ Fakulti Psikologi dan Pendidikan, Universiti Malaysia Sabah \\ Kota Kinabalu, Sabah, Malaysia
}

\begin{abstract}
The study was conducted to analyse the effect of a robotic program to primary school children. In order to succeed in a world increasingly dependent on technology, computational thinking is important. Computational thinking is considered as an important skill for students in 21-st learning century. Computational thinking provides basic knowledge in the design of generalization problem; decomposition, data representation, generalization, modeling, and algorithm. Educational robotics associated much with computational thinking and the subject of computer science through programming module has been emphasized by the education ministry recently and was introduced formally in the primary school curriculum, which focuses on solving technological problems. The instrument used to measure the technological problem solving is Technological Problem Solving Inventory (PSI-TECH). Quasi-experiments was implemented in this study, involved experimental group and control group which were equal in selected characteristics. The robotic and basic visual programming program conducted for 10 weeks, consistent with the school syllabus and activities. Data were collected before and after the program, and quantitative analysis of t-test and ANOVA were used. Result had shown a significance positive value for the experimental group after the program. This study contributes in the field of education, especially teachers in investigating the problem-solving skills among students. In addition, diversification of study in the field of robotics.
\end{abstract}

Keywords: Robotic in education, computational thinking, technological problem solving

\section{INTRODUCTION}

Era of digital and information technology in the 21st century learning centered on the usage of electronic gadgets, active self-learning and collaborative learning among students. Educational robotics which are in line with the digital age, has been taken seriously by society in addressing computational thinking in the concept of graphical programming among the children. Theoritically, using robotics for learning embedded around consturctionist learning. Constructionist learning is inspired by the constructivist theory that individual learners construct mental models to understand the world around them. However, constructionism holds that learning can happen most effectively when people are also active in making tangible objects in the real world. In this sense, constructionism is connected with experiential learning, and builds on Jean Piaget's epistemological theory of constructivism (Papert, S. ,1993).

The term "computational thinking" is the new ways of thinking and processing information in an increasingly digital era. Computational algorithm and thinking was first introduced about 1950s-1960s. Computational thinking provides basic knowledge in the design of a generalized solution to all fields of knowledge which involved decomposition, data representation, generalization, modeling, and algorithm. However, computational thinking was first described by Papert (1993), and later spearheaded by Jeannette Wing through her articles in 2006; an approach to solving problems, creating systems and understanding human behavior that leads to computational concepts. Nevertheless, computational thinking is difficult to measure and is broken down into sub-skills, thought processes involved in formulating the problem the solution and can be summarized into three stages: 
i) Summarizing the problem (abstract),

ii) Designing the solution (automation), and

iii) Implementation \& Evaluation (analysis)

One of the major issues among Malaysian students is the lack of problem solving skills; higher order thinking skills among students. Problem-based learning encourages students to use their knowledge content, applying critical thinking and problem solving skills in the real world .It emphasizes that learning occurs in the process of solving problems, not by memorizing content but by taking advantage of the cooperation and effort together with colleagues (Baek \& An, 2011). Problem-based learning process is divided into several phases: ddesign and evaluate issues and the implementation phase of planning, implementing, and evaluating the teaching-learning process (Trop \& Sage, 1998).

Meanwhile, technological problem solving approach involves a computer that thinks like a human being or encourage others to think like a computer, is achieved through computational thinking. The technological problem is usually solved by a system or gadgets (Mioduser, D. 2009; Voskoglou \& Buckley, 2012; Varnado, 2005). In educational robotics and programming, graphical programming is becoming increasingly popular among students through concepts that are easy to use by students, while applying technological problems (Brennan \& Resnick, 2012). Technological Problem Solving Inventory (PSI-TECH) is an instrument to measure technological problem solving, adapted from PSI-PSYCHProblem Solving Inventory (Wu, et al., (1996) dan MacPherson (1998).

The research question involved are:

(i) Are there any differences for control group in technological problem solving performance before and after the programme?

(ii) Are there any differences for experimental group in technological problem solving performance before and after the programme?

(iii) Are there any score differences between control and experimental group in techcnological problem solving performance before and after the programme?

(iv) Are there any differences between genders in technological problem solving performance after the programme?

(v) Are there any differences between gender in technological problem solving performance and robotic module assesment score?

In order to answer the research questions, these hypothesis were created as stated in Table 1:

Table 1 : Hyphothesis

\begin{tabular}{ll}
\hline Alternative hypothesis & Null hypothesis \\
\hline $\begin{array}{l}\text { 1. There are different levels of technological problem } \\
\text { solving performance of participants in the control group } \\
\text { test before and after the test. }\end{array}$ & $\begin{array}{l}\text { 1. No significant difference in the performance of } \\
\text { technological problem solving test participants in the } \\
\text { control group before and after the test. }\end{array}$ \\
\hline $\begin{array}{l}\text { 2. There are significant differences in the level of } \\
\text { performance of technological problem solving treatment } \\
\text { group participants after participating in a training program } \\
\text { with graphical programming with robotics. }\end{array}$ & $\begin{array}{l}\text { 2. There was no significant difference in the level of } \\
\text { performance of technological problem solving } \\
\text { treatment group after participating in a graphical } \\
\text { programming training program with robotics. }\end{array}$ \\
\hline $\begin{array}{l}\text { 3. There are differences score levels in technological } \\
\text { problem solving performance between the control group } \\
\text { and the treatment group before and after the training } \\
\text { modules. }\end{array}$ & $\begin{array}{l}\text { 3. No difference score level in technological problem } \\
\text { solving performance between the control group and the } \\
\text { treatment group before and after the training modules. }\end{array}$ \\
\hline $\begin{array}{l}\text { 4. There are differences in score level of technological } \\
\text { problem solving performance between genders after the } \\
\text { training modules. }\end{array}$ & $\begin{array}{l}\text { 4. No differences in score level of technological } \\
\text { problem solving performances between genders after } \\
\text { the training modules. }\end{array}$ \\
\hline $\begin{array}{l}\text { 5. There are differences in technological problem solving } \\
\text { performances score and overall training modules score } \\
\text { between genders. }\end{array}$ & $\begin{array}{l}\text { 5. No differences in technological problem solving } \\
\text { performances score and overall training modules score } \\
\text { between genders. }\end{array}$ \\
\hline
\end{tabular}


The 21st century dawned as the beginning of the Digital Age; a time of unprecedented growth in technology and its subsequent information explosion. The term "computational thinking" (CT) has been at the center of recent efforts to describe and promote new ways of thinking in an increasingly digital age. Computational thinking provides foundational knowledge in problem solving and design. Computational thinking is also a process that generalizes a solution to open ended problems. Therefore computational thinking is being considered as a critical skill for students in the $21^{\text {st }}$ century. Computational thinking (CT) was first described by Papert (1993), and then pioneered by Jeannette Wing. Jeannette Wing's (2006) influential article on computational thinking argued for adding this computational thinking competency to every child's analytical ability as a vital ingredient of science, technology, engineering, and mathematics (STEM) learning.

In details, computational thinking facilitates new ways of seeing existing problems, emphasizes creating knowledge rather than using information, presents possibilities for creatively solving problems ,and facilitates innovation (Dede, et al. 2013). It involves many skills, but programming abilities seem to be a core aspect since they foster the development of a new way of thinking that is the key to the solution of problems that require a combination of human power and computing power capacity (Ambrosio, et al, 2014). On the other hand, computational thinking is a problem solving methodology that uses the concepts of computer science such as abstraction, algorithms, problem decomposition, simulation and parallelism to solve problems not only in computer science but biology, chemistry, engineering, sociology, and other disciplines. It focuses on the development of an individual's ability to: (1) solve open-ended problems; (2) organize and analyze data; (3) identify possible solutions to a problem; (4) use abstraction to create models; and (5) collaborate in teams (Cury, J. et al., 2010 and Barr \& Stephenson, 2011). The terms stated below involved:

- Algorithm (or procedure, function): An algorithm is a set of rules that describe how to do something, or how to solve a problem. An algorithm may be described as a program, pseudo-code or a less formal step-by-step explanation (even a recipe).

- Data (or variable, database, queue): Data is the information that is part of the problem/question, as well how the information is organized and how it is accessed. Distances between neighboring cities are the data for the problem of computing distances between cities, for example.

- Abstraction (or conceptualization, modularization): Abstraction is the pulling out of important properties and the generalization of relationships.

- Iteration (or loops, recursion): Iterations involve the repetition of a procedure until a desired goal is reached. In math, iterations occur in long division. In science, it occurs in repeating a step of an experiment, until the desired condition is achieved. In game design and development, it happens in the construction of game versions, from initial prototype to the beta.

- Object: An entity that has certain properties and can perform certain actions. A human being, a car, or a calculator software application is all objects.

- Process: The execution of an explicit or implicit algorithm. A process could be a human being, a community, or a virus performing some actions. It can also be an actual running program or computer application.

- System: A system is a group of processes or objects that interact. A system could be computer network, a flock of birds, a social group including a virtual community, as well as larger entities like economies and biological systems.

Computational thinking related to higher order thinking Bloom's taxnomomy in application, analyze, synthesis dan evaluation (Voskoglou \& Buckley,2012), encouraged problem solving in more creative way (Dede, et al., 2013). Research shown after students involved in robotic program, computational thinking was detected in the participants conversation naturally (Grover, S. 2011). Hence, computational thinking was closely related to technological problem solving Atmatzidou \& Demetriadis (2014), involved programming terms such as (sequences), (loops), (parallelism), (events), (conditionals), and (operators) (Brennan \& Resnick ,2012). Brennan K. \& Resnick M. (2012) described computational thinking as being able to;

1. Understand what aspects of a problem are amenable to computation 
2. Evaluate the match between computational tools and techniques and a problem to understand the limitations and power of computational tools and techniques

3. Apply or adapt a computational tool or technique to a new use

4. Recognize an opportunity to use computation in a new way

5. Apply computational strategies such divide and conquer in any domain

Meanwhile, educational robotics and its programming known as a transformational tool for computational thinking, coding or programming, and engineering, all increasingly being viewed as critical ingredients of STEM (science, technology, engineering and math) learning in education (Eguchi, A. 2014, Afari E. \& Khine M.S.,2017). Research shown popular interest in robotics has increased astonishingly in the last few years. Fridin, M. (2014) showed that the children enjoyed interacting with the robot and accepted its authority. And robotics has been integrated in early childhood education, by integrating foundational programming and engineering concepts. Eventhough, the teachers involved had no prior experience using robotics in classroom before (Elkin, M. et al, 2014).Teaching robotics to young people frequently implies a constructivist approach which emphasizes "learning by doing" as the main teaching strategy (Bilotta, D. et al., 2009).

According to Alimisis (2013), robots are becoming an integral component of our society and have great potential in being utilized as an educational technology. Robotics has attracted the interest of teachers and researches as a valuable tool to develop cognitive and social skills for students from preschool to high school and to support learning in science, mathematics, technology, informatics and other school subjects or interdisciplinary learning activities. Kazakoff and Bers (2011) designed a study to investigate the impact of computer programming on sequencing ability in early childhood. The study demonstrated the potential of integrating robotics and computer programming into early childhood learning experiences. Children learned to program a robot to complete a variety of challenges and simultaneously improved their score on a sequencing assessment. Sequencing is daily life skills, from dividing our time into what we needto do first, second, and last; we understand events in our lives by understanding the order in which they occur. Programming and building robots can improve on the specific skills that are often related to science and mathematics such as sequencing skills, reasoning skills, metacognitive skill and etc.

On the other hand, Scrath is a popular open source for coding. Scratch is a computer programming language for children, with a graphical drag-and-drop user interface (Harvey \& Monig, 2010). S4A (Scratch for Arduino) is a drag and drop programming environment based on the MIT creation "Scratch". It has been modified to connect to an Arduino plugged in via USB, offering a variety of additional code blocks to implement and create scripts to control the Arduino and attached components.

Hence, solving problem which involves technology was called technological problem solving. Technological problem solving usually solved by utilizing a electronic gadjet or a computer. The solving process involved thinking and tinkering, seeking for the best solutions (Mioduser, D. 2009). Technological Problem Solving Inventory (PSI-TECH) is an instrument to measure technological problem solving, adapted from PSI-PSYCH-Problem Solving Inventory (Wu, et al., (1996) dan MacPherson (1998). PSI-PSYCH was invented by Heppner (1988), to accesss problem solving confidence, personal control and problem avoidence. Custer, et al., (2001) mentioned that the difference between PSI-PSYCH and PSI-TECH was PSI-TECH more focused on technological problem solving.

\section{METHODOLOGY}

This study applied a quantitative approach, involving instruments Techonological Problem Solving Inventory, PSI-TECH (Technological Problem Solving Inventory). Application of robotics and programming module for primary school (RPGsr) was the intervention for technological problem solving performance for the treatment groups. The quasi-experimental design was implemented; consist of prepost test among the control group dan experimental group (Ghazali \& Sufean, 2016) (Table 2). This design used after considering the particiants can't be distributed randomly prior to school requirements and the robotics programme duration. 
Table 2: The study design

\begin{tabular}{lll}
\hline Study design & Group & Tindakan \\
\hline Quasi experimental & Experimental & Pre test-intervention- post test \\
& Control & Pre test -No intervention- post test \\
\hline
\end{tabular}

After the factor analysis was done through the exploratory factor analysis, 4 items from 34 items in the technological problem solving inventory were eliminated. The 30 left items will be proceeding to confirmatory factor analysis. Random sampling was chosen to form 2 groups consist of experimental and control. Creswell (2009) recommend choosing a sample in total or by taking the entire sample in a class very appropriate to carry out a quasi-experimental for minimizing the interference with classroom learning. The sample is intended that students following the syllabus of the selected graphical programming Scratch; two classes of classes 6A and 6B are selected in the study as a treatment and control group with an average number of 35 participants. After took into considering school requirements based on the period of normal learning, school's holidays and also after taking into account the additional class and extra-curricular activities, this robotic programme run through 5 months with one contact period with participants every week. The entire selected participant is homogenous in term of STEM subjects' performance and they are currently immersed in the same standard curriculum of Malaysia primary school (Pálinkás, et al,, 2013).

\section{RESULTS}

The exploratory factor analysis was done for Technological Problem Solving Inventory (PSI-TECH) to explore both the validity and realibilty of the questionnaire which was translated to Bahasa Malaysia and has been applied in different demography and geography. Validity of an instrument involves the extent of which will be used to examine how far the instrument measured the intended construct. While the reliability of the instrument questionnaires explaining the extent to which scores in each item was consistent or stable when tested repeatedly (Ghazali \& Sufean, 2016). Comments from a local criterion and statistics expert was considered for strengthening the face validity which was to verify that the items constructed representing the construct being measured, including the correct use of language, spelling and phrase sentences. While the content validity refers to the extent to which the items in the instrument has been representing all aspects tested.

The result, Table 3 shows the Bartlet test was significant (P-value <0.05). At the same time, the measure of sampling adequacy (Measure of Sampling Adequacy) by Kaiser-Meyer-Olkin (KMO) is 0678, higher than the minimum 0.6 (Awang, 2010; 2012; Hoque et al., 2016). Both of these achievements (Bartlet test was significant, and the KMO>0.6) reflects the data is worth for the next procedure in the exploration factor analysis (EFA) (Awang, 2010; 2012; Hoque et al., 2016).

Table 3: KMO and Bartlet test value

\begin{tabular}{llr}
\hline Kaiser-Meyer-Olkin Measure of Sampling Adequacy. & .905 \\
\hline Bartlett's Test of Sphericity & Approx. Chi-Square & 2915.663 \\
& df & 561 \\
& Sig. & .000 \\
\hline
\end{tabular}

The internal reliability of the instrument is estimated using Cronbach Alpha value. Alpha value of an instrument must be over the minimum limit of 0.7 to be adopted in the next study. Table 4 shows the Alpha value of items that measure the construct. Items have surpassed Alpha value of 0.7 and a minimum value can be adopted in this study (Awang, 2010; 2012; Hoque et al., 2016). Reliability is the degree of accuracy and precision of the measurements made by the instrument. The smaller the degree of error for the instrument, hence increasing the reliability of the instrument (Ranjit Kumar, 1999). 
Table 3: Cronbach's Alpha value for each component

\begin{tabular}{ccc}
\hline Component & Cronbach's Alpha \\
\hline 1 & 12 & $\mathbf{0 . 9 6 8}$ \\
\hline 2 & 8 & $\mathbf{0 . 9 4 7}$ \\
\hline 3 & 10 & $\mathbf{0 . 9 4 4}$ \\
\hline
\end{tabular}

\section{DATA ANALYSIS}

Inference and descriptive statistics are used in testing the research hypotheses. To test the hypothesis I paired t-test was used to analyse the performance of technological problem solving differences in the control group before and after the program.Table 5 (a) and (b) below shows the results of the independent t-test (pair sample t-test) for the analysis of test score mean difference of the control group before and after the program. The group consisted of 39 respondents. The scores for the control group before the program is 230.6923 and 230.6667 score after is. As the value of alpha (.831) is more than the level of regulation (.025), the null hypothesis is accepted that failed rejected; namely that there was no significant difference in the mean score for the control group before and after the program. This conclusion was made on the level of significance alpha $=.05(5 \%)$ or the level of confidence $(95 \%)$. This decision means that the control group who did not follow the program does not receive any effect because the teaching is to follow the normal teaching methods in the classroom.

Table 5 (a) : T-test for control group.

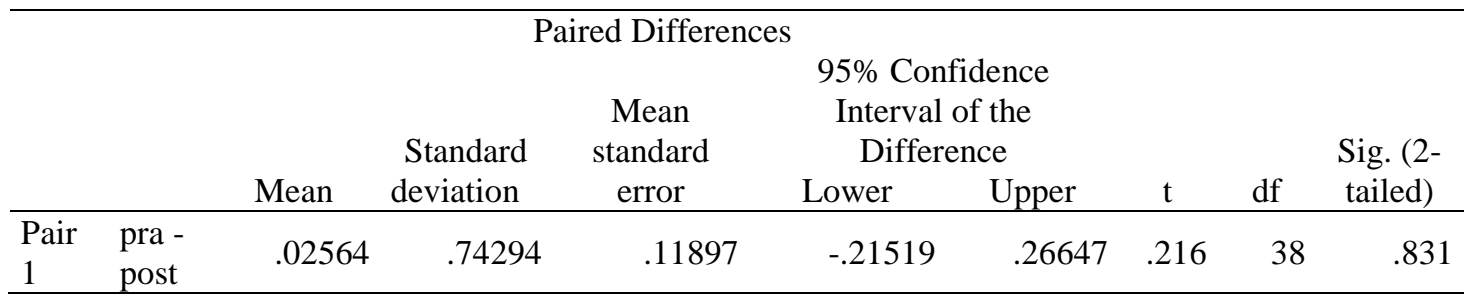

Jadual 5 (b) : Descriptives analysis for control group.

\begin{tabular}{|c|c|c|c|c|c|}
\hline & & Min & $\mathrm{N}$ & $\begin{array}{l}\text { Standard } \\
\text { deviation }\end{array}$ & $\begin{array}{l}\text { Mean standard } \\
\text { error }\end{array}$ \\
\hline \multirow[t]{2}{*}{ Pair 1} & Pra & 230.6923 & 39 & 24.11612 & 3.86167 \\
\hline & Post & 230.6667 & 39 & 24.01242 & 3.84507 \\
\hline
\end{tabular}

To test the hypothesis II paired t-test was used to test the performance of technological problem solving in treatment group; whether have increased significantly after participating in graphical programming with robotics, to prove the effectiveness of this treatment. Table 6 (a) and (b) below shows the results of the independent t-test (pair sample t-test) for the analysis of test score mean difference of treatment group before and after the program. The group consisted of 30 respondents. The scores for the treatment group before the program is 217.60 and 236.10 after the program. As the value of alpha (.003) is less than the level of regulation (.025), then the alternative hypothesis is accepted hypothesis null is successfully rejected; that there are significant differences in the mean scores for the treatment group before and after the program. This conclusion was made on the level of significance alpha $=.05(5 \%)$ or the level of confidence (95\%). This result mean's that the treatment group who involve in the program has received a positive impact of teaching modules for technological problem solving performance level was increasing. 
Jadual 6 (a): T-test for experimental group.

\begin{tabular}{|c|c|c|c|c|c|c|c|c|}
\hline \multicolumn{9}{|c|}{ Paired Differences } \\
\hline & \multirow[b]{3}{*}{ Mean } & \multirow{3}{*}{$\begin{array}{c}\text { Standard } \\
\text { deviatiion }\end{array}$} & \multirow{3}{*}{$\begin{array}{l}\text { Mean } \\
\text { standard } \\
\text { error }\end{array}$} & \multirow{2}{*}{\multicolumn{2}{|c|}{$\begin{array}{l}95 \% \text { Confidence } \\
\text { Interval of the } \\
\text { Difference }\end{array}$}} & \multirow[b]{3}{*}{$\mathrm{t}$} & \multirow[b]{3}{*}{ df } & \multirow{3}{*}{$\begin{array}{l}\text { Sig.(2- } \\
\text { tailed) }\end{array}$} \\
\hline & & & & & & & & \\
\hline & & & & Lower & Upper & & & \\
\hline $\begin{array}{c}\text { Pair } 1 \text { preRawatan - } \\
\text { postRawatan }\end{array}$ & -18.50000 & 31.52859 & 5.75631 & -30.27297 & -6.72703 & -3.214 & 29 & .003 \\
\hline
\end{tabular}

Jadual 6 (b): Descriptives analysis for experimental group.

\begin{tabular}{|c|c|c|c|c|c|}
\hline & & Mean & $\mathrm{N}$ & $\begin{array}{l}\text { Standard } \\
\text { deviation }\end{array}$ & $\begin{array}{c}\text { Mean standard } \\
\text { error }\end{array}$ \\
\hline \multirow{2}{*}{ Pair 1 } & preRawatan & 217.6000 & 30 & 33.05231 & 6.03450 \\
\hline & postRawatan & 236.1000 & 30 & 25.96729 & 4.74096 \\
\hline
\end{tabular}

To test the hypothesis III paired t-test was used to examine the differences in technological problem solving score level participants between the control group and the treatment group before and after the training modules. Table 7 is the result of analysis for the control group and the treatment group before the program schedule and table 8 is the analysis of the treatment and control groups after the program.

Table 7: T-test value before the program, for control and experimental group.

\begin{tabular}{|c|c|c|c|c|c|c|c|c|}
\hline \multicolumn{9}{|c|}{ Paired Differences } \\
\hline & \multirow[b]{3}{*}{ Mean } & \multirow{3}{*}{$\begin{array}{l}\text { Standard } \\
\text { deviation }\end{array}$} & \multirow{3}{*}{$\begin{array}{l}\text { Mean } \\
\text { standard } \\
\text { error }\end{array}$} & \multirow{2}{*}{\multicolumn{2}{|c|}{$\begin{array}{l}95 \% \text { Confidence } \\
\text { Interval of the } \\
\text { Difference }\end{array}$}} & \multirow[b]{3}{*}{$\mathrm{t}$} & \multirow[b]{3}{*}{$\mathrm{df}$} & \multirow{3}{*}{$\begin{array}{l}\text { Sig. (2 } \\
\text { tailed) }\end{array}$} \\
\hline & & & & & & & & \\
\hline & & & & Lower & Upper & & & \\
\hline air 1 praKawala & & & & & & & & \\
\hline $\begin{array}{l}\mathrm{n}- \\
\text { preRawata } \\
\mathrm{n}\end{array}$ & 14.000 & 46.046 & 8.407 & -3.194 & 31.194 & 1.665 & 29 & .107 \\
\hline
\end{tabular}

Based on the table 7 above, since the probability obtained (.107) is more than the specified alpha value (.025), then the null hypothesis stated there is no significant differences in score level technological problem solving performances between the control group and the treatment group before training module was failed in rejection and accepted. It was confirmed that the group of students was at the same level of performance before the program. It shown, a fair comparison was done to monitor the effect of the program before and after the program.

Table 8: T-test value after the program, for control and experimental group.

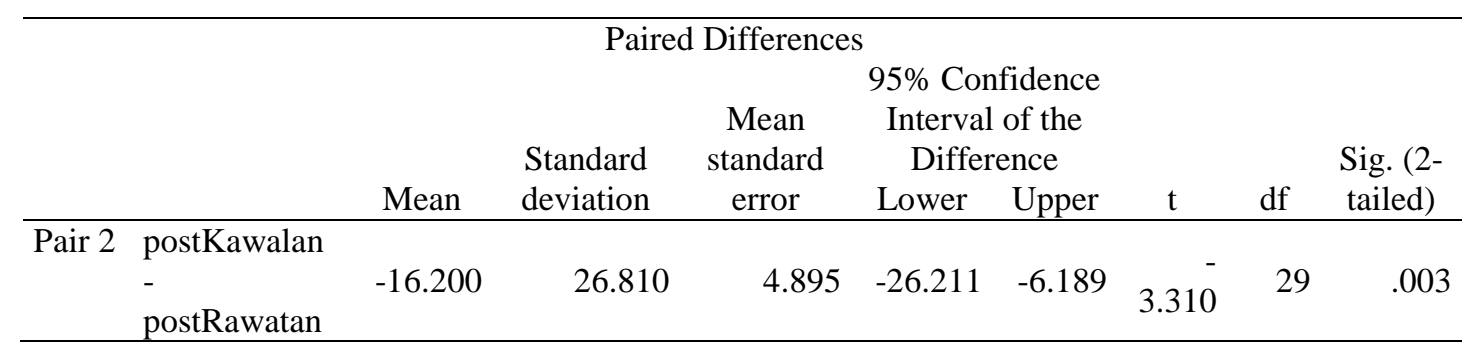

Based on Table 8 above, the probability value obtained (.003) is less than the specified alpha value (.025), the null hypothesis stated there is no difference score level in technological problem solving performance between the control group and the treatment group after training module was successfully rejected and the 
alternative hypothesis is accepted. Mean value that is a difference in score level technological problem solving between the control group and the treatment group after the training modules. The program has managed to have an impact on student achievement for technological problem solving.

To test the hypothesis IV t-test analysis was used to examine differences in score level technological problem solving between gender treatment group participants after the training modules. Table 9(a) and (b) below are the results of the analysis.

Table 9 (a): Descriptives analysis between gender for treatment group.

\begin{tabular}{|c|c|c|c|c|c|}
\hline & Gender & $\mathrm{N}$ & Mean & $\begin{array}{l}\text { Standard } \\
\text { deviation }\end{array}$ & $\begin{array}{l}\text { Mean standard } \\
\text { error }\end{array}$ \\
\hline \multirow[t]{2}{*}{ postRawatan } & 1 & 14 & 226.000 & 25.625 & 6.848 \\
\hline & 2 & 16 & 239.000 & 25.972 & 6.493 \\
\hline
\end{tabular}

Table 9(b): T-test value between gender for treatment group.

\begin{tabular}{|c|c|c|c|c|c|c|c|c|c|c|}
\hline & & $\begin{array}{r}\text { Leve } \\
\text { Test } \\
\text { Equal } \\
\text { Varia }\end{array}$ & $\begin{array}{l}\text { fe's } \\
\text { for } \\
\text { ty of } \\
\text { hces }\end{array}$ & & & t-test fo & r Equalit & $\mathrm{y}$ of $\mathrm{Me}$ & & \\
\hline & & & & & & Sig. (2- & $\begin{array}{c}\text { Mean } \\
\text { Differe }\end{array}$ & $\begin{array}{l}\text { Std. } \\
\text { Error } \\
\text { Differ }\end{array}$ & $\begin{array}{r}95 \% \mathrm{Co} \\
\text { Interva } \\
\text { Diffe }\end{array}$ & $\begin{array}{l}\text { fidence } \\
\text { of the } \\
\text { ence }\end{array}$ \\
\hline & & $\mathrm{F}$ & Sig. & $\mathrm{t}$ & $\mathrm{df}$ & tailed) & nce & ence & Lower & Upper \\
\hline $\begin{array}{l}\text { postRawata } \\
\text { n }\end{array}$ & $\begin{array}{l}\text { Equal } \\
\text { variances } \\
\text { assumed }\end{array}$ & .133 & .719 & 1.376 & 28 & .180 & 13.000 & 9.446 & -32.349 & 6.349 \\
\hline & $\begin{array}{l}\text { Equal } \\
\text { variances not } \\
\text { assumed }\end{array}$ & & & $\begin{array}{r}- \\
1.378\end{array}$ & $\begin{array}{r}27.56 \\
9\end{array}$ & .179 & 13.000 & 9.437 & -32.345 & 6.345 \\
\hline
\end{tabular}

Based on the table above 9, Levene test for equality of variances are not significant $(\mathrm{p}=.719>$ .05) showed that both groups of boys and girls have the same variance. That is, the null hypothesis that the variance of the group of boys is equal to the variance of the group of female students failed rejected. Thus, the results of t-test for equality of means of two groups independent of the sample which has the same population variance is taken into account (equal variances assumed).

Given the specified alpha (.18) is more than the specified alpha value (.025), the null hypothesis rejection was fail. That is, there was no significant difference in mean scores between technological problems solving group of boys than girls. Group of boys had a mean score of (226) while the female students had a mean score of (239). However, the mean difference was not significant at the .05 level of significance alpha $(5 \%)$.

To test the hypothesis V MANOVA was used to examine differences in technological problem solving score and training modules score between genders.

Table 10(a): The number of male and female participants.

\begin{tabular}{llr}
\hline & \multicolumn{2}{c}{$\mathrm{N}$} \\
\hline Gender & 1 & 14 \\
& 2 & 16 \\
\hline
\end{tabular}

Table 10 (a) shows the number of male students $(\mathrm{N}=14)$ and the number of female students $(\mathrm{N}=$ 16) whom achievement was compared. 
Table 10(b): Descriptive statistics.

\begin{tabular}{llrrr}
\hline & Gender & \multicolumn{1}{c}{ Mean } & $\begin{array}{l}\text { Standard } \\
\text { deviation }\end{array}$ & $\mathrm{N}$ \\
\hline Technological & 1 & 242.0000 & 22.85069 & 14 \\
Problem Solving & 2 & 253.2500 & 24.10118 & 16 \\
& Total & 248.0000 & 23.81393 & 30 \\
\hline Module score & 1 & 77.9286 & 7.25857 & 14 \\
& 2 & 81.4375 & 6.07694 & 16 \\
& Total & 79.8000 & 6.77419 & 30 \\
\hline
\end{tabular}

Table 10 (b) shows the mean and standard deviation for technological problem solving (post treatment score) and scores of training modules by gender. According to the analysis, the mean oftechnological problem solving for boys (242) is lower than female students (253.25). So is the case with a score of training modules, with a mean of boys (77.92) than girls (81.44).

Table 10(c): Box's M analysis.

\begin{tabular}{lr}
\hline Box's M & 2.752 \\
\hline F & .846 \\
\hline df1 & 3 \\
\hline df2 & 397445.475 \\
\hline Sig. & .469 \\
\hline
\end{tabular}

Box's $M$ test is used to test the homogeneity of variance-covariance matrix of the dependent variables. Box's $M$ test is not significant (.469) in excess of 0.001 demonstrates the variancecovariance matrix is homogeneous between the dependent variable being studied.

Table 10(d): Multivariate tests.

\begin{tabular}{llrrrrr}
\hline Effect & & \multicolumn{1}{c}{ Value } & \multicolumn{1}{c}{ F } & Hipotesis df & \multicolumn{1}{c}{ Error df } & \multicolumn{1}{c}{ Sig. } \\
\hline Intercept & Pillai's Trace & .994 & $2070.307^{\mathrm{b}}$ & 2.000 & 27.000 & .000 \\
& Wilks' Lambda & .006 & $2070.307^{\mathrm{b}}$ & 2.000 & 27.000 & .000 \\
& Hotelling's Trace & 153.356 & $2070.307^{\mathrm{b}}$ & 2.000 & 27.000 & .000 \\
& Roy's Largest Root & 153.356 & $2070.307^{\mathrm{b}}$ & 2.000 & 27.000 & .000 \\
\hline Gender & Pillai's Trace & .069 & $1.002^{\mathrm{b}}$ & 2.000 & 27.000 & .380 \\
& Wilks' Lambda & .931 & $1.002^{\mathrm{b}}$ & 2.000 & 27.000 & .380 \\
& Hotelling's Trace & .074 & $1.002^{\mathrm{b}}$ & 2.000 & 27.000 & .380 \\
& Roy's Largest Root & .074 & $1.002^{\mathrm{b}}$ & 2.000 & 27.000 & .380 \\
\hline
\end{tabular}

a. Design: Intercept + Jantina

b. Exact statistic

Based on Table 10 (d), in view of the probability obtained (Pillai's Trace $=.380$, for gender) more than the specified alpha (.05), the rejection of null hypothesis failed. There is no strong evidence to conclude that there are significant differences in the mean combination of technological problem solving and module score betweem gender.

\section{DISCUSSION}

The study was conducted to analyse the effect of a robotic programme to primary school children. By evaluation research, via quasi experimental research prosedure the result obtained was positive. Besides that, to support the analysis result by quantitative analysis on the other hand qualitative data can be applied such as focus interview or document analysis. However, the overall result may be varied depending on demographical and geographical data. 
In this program, the focus group was primary school students in Miri, Sarawak only. To obtain more rigorous analysis for cross-sectional studies, the program can be run in other district and the result within district can be compared. However, the overall program was much more depending on the time length and budget provided. Other than that, longitudinal studies can be considered by changing the time series.

Meanwhile,the analysis involved three variables which were genders, technological problem solving and module scores. Alternatively, other variables can be consider such as motivation and interest level.

\section{REFERENCES}

Afari E. \& Khine M.S. (2017). Robotics as an educational tool. International Journal of Information and Education Technology. 7 (6):437-442.

Alimisis, D. (2013). Educational robotic: Open questions and new challenges. Themes in Science \& Technology Education, 6(1): 63-71.

Ambrosio, A. P., Almeida,L.D.S., Macedo, J. \& Franco, A. (2014). Exploring core cognitive skills of computational thinking, University of Sussex.

Atmatzidou, S. \& Demetriadis, S. (2014). How to support students' computational thinking skills in educational robotics activities, Proceedings of the $4^{\text {th }}$ International Workshop Teaching Robotics, Teaching with Robotics \& $5^{\text {th }}$ International Conference Robotics in Education, July 18, Padova, Italy.

Awang, Z. (2010). Research Methodology for Business and Social Sciences. Kelantan: Universiti Teknologi MARA.

Awang, Z. (2012). Research methodology and data analysis. Penerbit Universiti Teknologi MARA Press.

Baek, H-G., \& An, K-S. (2011). Study of the development of a problem-based model for mind study. Korean Journal of Digital Policy \& Management, 9 (3): 249-260.

Barr, V. \& Stephenson, C. (2011). Bringing computational thinking to K-12: what is involved and what is the role of the computer science education community? ACM Inroads, 2(1): 48-54.

Bilotta, D., Gabriele, D., Servidio, R. \& Tavernise, A. (2009). "Edutainment robotics as learning tool", in Z. Pan, A., Chcok, W. Muller and M. Chand (eds), Transactions on Edutainment III, Lecture Notes in Computer Science 5940, pp.25-35.

Brennan K.\& Resnick M. (2012). New frameworks for studying and assessing the development of computational thinking, AERA meeting, Canada.

Creswell, J.W. (2009). Research Design (Qualitative, Quantitative and Mixed methods Approaches) 3rd edition. London: Sage Publications.

Cury, J., Snyder, L., and Wing, J. (2010). Computational Thinking: A Definition. Demystifying Computational Thinking for Non-Computer Scientists (in press).

Dede, C., Mishra, P. \& Voogt, J. (2013). Working group 6: Advancing computational thinking in $21^{\text {st }}$ century learning. International Summit on ICT in Education.

Eguchi, A. (2014). Robotics as a learning tool for educational transformation. In Proceedings of $4^{\text {th }}$ International Workshop Teaching Robotics, Teaching with Robotics \& $5^{\text {th }}$ International Conference Robotics in Education, 18 July (pp. 27-34), Padova, Italy.

Elkin, M., Sullivan, A., \& Bers, M. U. (2014). Implementing a robotics curriculum in an early childhood Montessori classroom. Journal of Information Technology Education: Innovations in Practice, 13, 153-169. Retrieved from http://www.jite.org/documents/Vol13/JITEv13IIPvp153-169Elkin882.pdf

Fridin, M. (2014) Storytelling by a kindergarten social assistive robot: A tool for constructive learning in preschool education. Computers \& Education, 70 : 53-64.

Ghazali Darusalam dan Sufean Hussin. (2016). Metodologi Penyelidikan Dalam Pendidikan. Kuala Lumpur: Universiti Malaya.

Grover, S. (2011). Robotics and engineering for middle and high schools students to develop computational thinking, Annual Meeting of the American Educational Research Association, p.p 1-15.

Harvey, B. \& Monig, J. (2010). Bringing "no ceiling" to Scratch: Can one language serve kids and computer scientists? Constructionism, Paris.

Heppner. (1988). The problem solving inventory manual. Palo Alto, CA: CPP, Inc.

Hoque, A. S. M. M., \& Awang, Z. (2016). The Exploratory Factor Analysis (EFA) of Entrepreneurial Marketing Scale - Development and Validation. Tourism Conference, 20-22 april (p. 22).

Jeannette M.Wing. (2006). Computational Thinking Viewpoint. Communications of the ACM. 49 (3), 33-35. 
Kazakoff, E.R., Sullivan, A. \& Bers, M.U. (2013). The effect of a classroom-based intensive robotics and programming workshop on sequencing ability in early childhood. Early Childhood Education Journal, 41: 245255.

Kazakoff, E.R. \& Bers, M.U. (2011). The impact of computer programming on sequencing ability in early childhood. AERA.

Kazakoff, E.R. \& Bers, M.U. (2014). Put your robot in, put your robot out: Sequencing through programming robots in early childhood. Journal Educational Computing Research, 50(4) : 553-573.

Kazakoff, E.R. \& Bers, M.U. (2012). Programming in a robotics context in the kindergarten classroom: The impact on sequencing skills. Journal of Educational Multimedia and Hypermedia, 21(4) : 371-391.

MacPherson, R.T. (1998). Factors affecting technological trouble shooting skills. Journal of Industrial Teacher Education, 35(4).

Mioduser, D. (2009). Learning technological problem solving - A cognitive/epistemological perspective. In A.T. Jones \& M.J. de Vries (ed.). International Handbook of Research and Development in Technology Education., pp.1-19. Sense Publishers.

Palinkas, L.A., Horwitz, S.M., Green, C.A., Wisdom, J.P., Duan,N. \& Hoagwood, K. (2013). Purposeful sampling for qualitative data collection and analysis in mixed method implementation research. Adm Policy Ment Health. DOI 10.1007/s10488-013-0528-y.

Papert, S. (1993). Mindstroms: Children, computers, and powerful ideas (2 ${ }^{\text {nd }}$ edition), NY : Basic Books.

Papert, S. (1993). The Children's Machine. New York: Basic Books, p. 86.

Ranjit Kumar. (1999). Research Methodology: A step-by-step guide to beginners. London: Sage Publications.

Trop, L., \& Sage, S. (1998). Problems as possibilities: Problem based-learning for K-12. Alexandria, VA: Association for Supervision and Curriculum Development.

Varnado, T.E. (2005). The Effects of a Technological Problem Solving Activity on FIRST LEGO League Participants' Problem Solving Style and Peformance. Phd Thesis. Virginia Polytechnic Institute and State University.

Voskoglou, M.G. \& Buckley, S. (2012). Problem solving and computers in a learning environment, Egyptian Computer Science Journal (ECS), 36(4), 28-46.

Wu, T., Custer, R. L., \& Dyrenfurth, M. J. (1996). Technological and personal problem solving styles: Is there a difference? Journal of Technology Education, 7(2):55-71. 